\title{
熱分解吸熱反応燃料の吸熱量の測定と評価*1 \\ Experimental Measurements and Verification of Heat Absorption of Endothermic Fuel
}

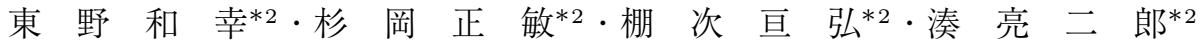 \\ Kazuyuki Higashino, Masatoshi Sugioka, Nobuhiro Tanatsugu, Ryojiro Minato, \\ 笹 山容 資*3. 磯 田 浩 志*3 \\ Yosuke SASAYAma and Hiroshi IsOdA
}

Key Words : Endothermic Fuel, Methylcyclohexane, Endothermic Effect

\begin{abstract}
The pyrolysis of Methylcyclohexane (MCH) is investigated for the purpose of a regenerative cooling system of hypersonic propulsion by using Endothermic Fuel (EF). The experimental apparatus has heating tube made from INCONEL alloy where MCH would pass through and be decomposed. To confirm the effects of endothermic reaction on the heat absorption, heat fluxes are measured at 9 cross sections in this heating tube. For each section, temperatures are measured at the inner and the outer radii of heating tube and heat flux can be evaluated by these temperature differences. The experimental results show that the endothermic reaction of $\mathrm{MCH}$ can confine the temperature increment of $\mathrm{MCH}$ in the heating tube and increase the heat fluxes when its temperature was greater than $900 \mathrm{~K}$. The numerical simulation can also indicate that $\mathrm{MCH}$ pyrolysis have begun around the same temperature. The chemical heat capacity by $\mathrm{MCH}$ pyrolysis can increase its total heat capacity to 1.4 times. These facts indicate the usefulness of the endothermic fuels and the possibilities of the regenerative cooling by them.
\end{abstract}

\section{1. 緒言}

次世代の航空宇宙輸送システムの開発においては, 高速 飛翔体環境特有の機体への熱負荷量増加やエンジン燃焼温 度上昇が懸念されるため, より一層効率的な冷却システム が求められる。再生冷却システムはこのような技術要求を 満足する手段の 1 つである。そしてシステム構築において は燃焼性能と冷却性能の最適化が不可欠である.

液体水素は, 単位質量当たりの発熱量, 比熱及び熱伝導 率が大きいことから極超音速機の燃料の一候補として挙げ られており, 再生冷却システムに適応する。しかし密度が 低いため燃料タンクの大型化が避けられないという設計上 の課題がある.

一方, 炭化水素燃料は液体水素と比較して, 単位質量当 たりの比熱や発熱量が小さいが, 密度は液体水素の 11 倍で ある。従って, 燃料夕ンクは液体水素を用いる場合と比較 して大幅に小型化できるため, 機体設計上有利である. 第 1 表に, 液体水素と炭化水素燃料の主要成分の 1 つであるメ チルシクロヘキサン（Methylcyclohexane, MCH）の物性 值を示した. $\mathrm{MCH}$ は, 環状飽和炭化水素化合物の一種で シクロヘキサンにメチル基が 1 個付いた構造である. 環状

\footnotetext{
*1 (C) 2012 日本航空宇宙学会

平成 22 年 11 月 19 日, 第 54 回宇宙科学技術連合講演会におい て発表. 平成 23 年 1 月 7 日原稿受付

$* 2$ 室蘭工業大学航空宇宙機システム研究センター

*3 室蘭工業大学大学院工学研究科航空宇宙システム工学専攻
}

飽和炭化水素化合物は JP-7 や Jet A1 といった航空用燃料 に 20〜30 vol\%程度含まれており，広く一般的に用いられ ている ${ }^{1)}$. 従って MCH のような炭化水素化合物の熱分解 時の吸熱特性を明らかにすることによって新たな再生冷却 システムの構築が期待される ${ }^{2)}$. このように燃料の熱分解反 応を再生冷却に利用する試みが積極的に研究されている3).

$$
\text { 2. 目的 }
$$

前章で述べたように, 熱分解反応時における吸熱量を再生 冷却に利用できる炭化水素燃料を熱分解吸熱反応燃料（Endothermic Fuel）という。本研究では, 熱分解吸熱反応燃 料を将来の極超音速機の再生冷却システムに適用する可能 性を検討するため, 炭化水素燃料の主成分であるメチルシ クロヘキサン $\left(\mathrm{MCH}: \mathrm{C}_{6} \mathrm{H}_{11} \mathrm{CH}_{3}\right)$ の加熱試験を行い, 熱 分解反応と吸熱量に関する基礎デー夕を計測することを目 的とする。

\section{3. 試 験 方 法}

3.1 供試燃料 本研究で使用した $\mathrm{MCH}$ は関東化学 (株) 製で，成分は純度 $98[\%]$ 以上，水分 $0.1[\%]$ 以下である. $\mathrm{MCH}$ は白金等の触媒の下で加熱し続けると以下のような 脱水素反応 (熱分解反応) を起こして，トルエンと水素を 生成することが知られている。

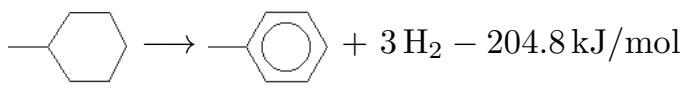


第 1 表 大気圧下での液体水素と炭化水素系燃料の比較

\begin{tabular}{llcc}
\hline & & $\begin{array}{c}\text { 液体水素 } \\
\left(\mathrm{LH}_{2}\right)\end{array}$ & $\begin{array}{c}\text { 炭化水素燃料 } \\
(\mathrm{MCH})\end{array}$ \\
\hline 貯蔵時の温度 $(\mathrm{K})$ & & 20 & 300 \\
密度 $\left(\mathrm{kg} / \mathrm{m}^{3}\right)$ & 70 & 774 \\
貯蔵温度から $800 \mathrm{~K}$ までの熱容量 & {$[\mathrm{MJ} / \mathrm{kg}]$} & 11.70 & 1.61 \\
& {$\left[\mathrm{MJ} / \mathrm{m}^{3}\right]$} & 819.2 & 1243.6 \\
蒸発潜熱 $(\mathrm{kJ} / \mathrm{kg})$ & {$[\mathrm{MJ} / \mathrm{kg}]$} & 0.45 & 0.32 \\
$298.15 \mathrm{~K}$ における比熱 & {$\left[\mathrm{MJ} / \mathrm{m}^{3}\right]$} & 31.39 & 246.72 \\
& {$[\mathrm{~kJ} /(\mathrm{kg} \mathrm{K})]$} & 14.30 & 1.84 \\
酸素との燃焼における低位発熱量 & $\left.\left[\mathrm{kJ} / \mathrm{m}^{3} \mathrm{~K}\right)\right]$ & 1001.3 & 1423.5 \\
& {$[\mathrm{MJ} / \mathrm{kg}]$} & 119.95 & 43.72 \\
& {$\left[\mathrm{GJ} / \mathrm{m}^{3}\right]$} & 8.40 & 33.84 \\
\hline
\end{tabular}

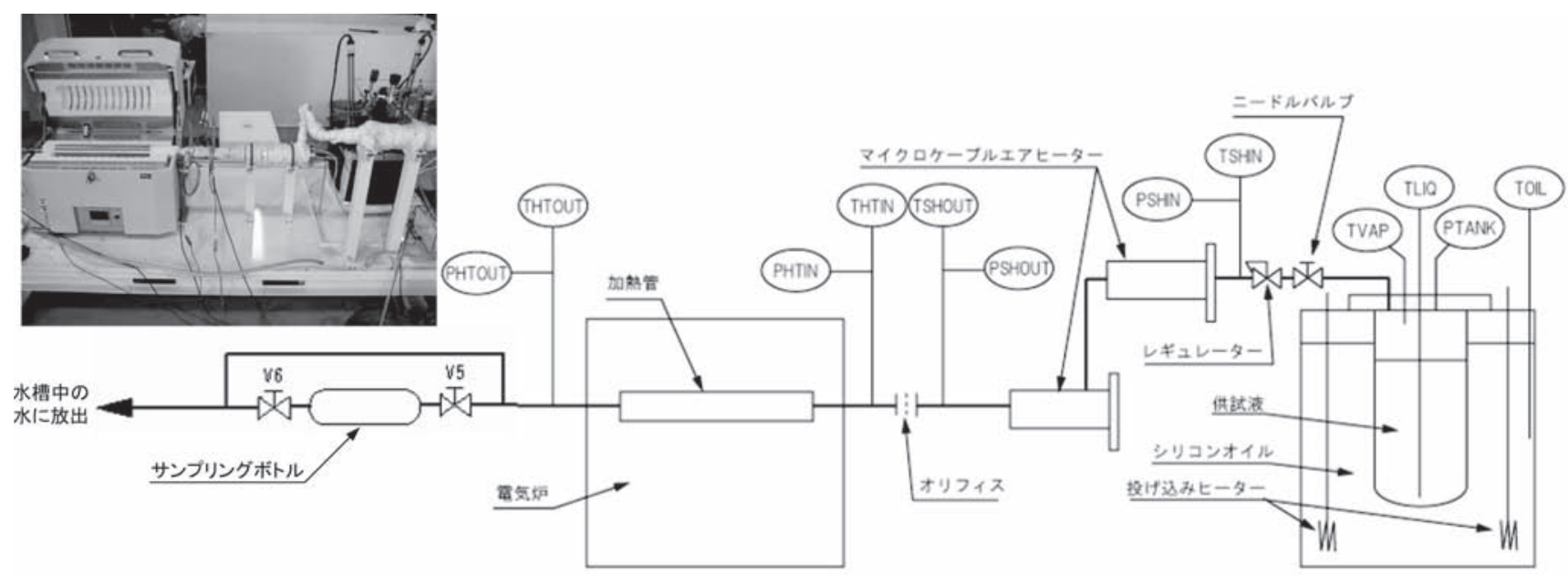

第1図 試験装置概要

熱分解に伴う吸熱量は, 反応物と生成物の生成エンタル ピー差で決定される。この脱水素反応では $204 \mathrm{~kJ} / \mathrm{mol} の$ 吸熱量があり, $\mathrm{MCH}$ の燃焼熱 $(4564 \mathrm{~kJ} / \mathrm{mol})$ に対して比 較的大きな吸熱量を有しているので再生冷却には有利にな る。一方, $\mathrm{MCH}$ を液体の状態から $800 \mathrm{~K}$ まで加熱するの に必要なエンタルピーは $1.61 \mathrm{MJ} / \mathrm{kg}(157.6 \mathrm{~kJ} / \mathrm{mol})$ であ る. 脱水素反応に伴う吸熱量はそれより大きいので, 熱分 解吸熱反応を冷却に用いることは極めて有効である。一般 的に炭化水素燃料を加熱するとコーキングを起こして煤を 生成し，それが燃料配管内に蓄積されると燃料配管の狭窄 や，熱伝達の低下を引き起こす可能性がある。しかしトル エンは，安定なベンゼン環にメチル基が付いた構造を持っ ており，比較的コーキングを起こしにくい特性がある。そ のため適当な触媒によって脱水素反応が起こるように反応 をコントロールすれば, $\mathrm{MCH}$ は熱分解吸熱反応燃料とし て実用化が期待できる。 また $\mathrm{MCH}$ は人体に対しては麻酔 作用があるとの報告4) があるものの，大量に摂取しない限 り際立った毒性がないので，扱い易い燃料でもある.

3.2 試験内容と実験装置 第 1 図に本試験で使用した 加熱装置の概略を示す. $\mathrm{MCH}$ 液槽は図の右側に位置して いるシリコンオイル液槽内に, $2 \mathrm{~kW}$ の投げ込みヒーター 2 個とともに設置されている。この投げ込みヒーターはシ リコンオイルを加熱し, $\mathrm{MCH}$ は加熱されたシリコンオイ
ルを介して約 $433 \mathrm{~K}$ まで加熱される。気化した $\mathrm{MCH}$ の蒸 気 (圧力約 $0.2 \mathrm{MPaG}$ ) は, 2 つのマイクロケーブルエアー ヒーター (各 $3 \mathrm{~kW})$ によって, 熱分解が起こる手前の温度 $(773 \mathrm{~K}$ 以下) まで加熱される。 そして電気炉 $(3.4 \mathrm{~kW}$, 光 洋サーモシステム, KTF-050N1）内に設置された加熱管を 通って, 熱分解反応を伴う場合の熱流束の計測を行う. 加 熱管を通過したガスは，加熱管の下流に設置されたサンプ リングボトルに貯気されて, 試験終了後にガスクロマトグ ラフによる成分分析に供される。 ガスサンプリングされな かった加熱ガスは，有害物質が発生し拡散する可能性があ るため, 水槽中の水へ排出されるようにした。電気炉内に設 置された加熱管は，第 2 図に示されたような全長 $500 \mathrm{~mm}$, 外径 $63 \mathrm{~mm}$, 内径 $5 \mathrm{~mm}$ の円筒形状になっており, その材 質は代表的な高温材料である INCONEL600である。加熱 管では管壁の内側と外側に熱電対を設置して, 管壁の温度 差を計測できるようにしている。これによって加熱管から $\mathrm{MCH}$ への伝熱量を把握することができる.

加熱量のコントロールは, 電気炉の加熱設定温度を $773 \mathrm{~K}$ から $1273 \mathrm{~K}$ まで $50 \mathrm{~K}$ 刻みで変化させることによって行 った。

加熱管における $\mathrm{MCH}$ への伝熱量は以下のように求めら れる。電気炉から燃料への単位加熱管長さ当たりの伝熱量 は円筒内の伝熱方程式より, 異なる加熱管半径位置での温 


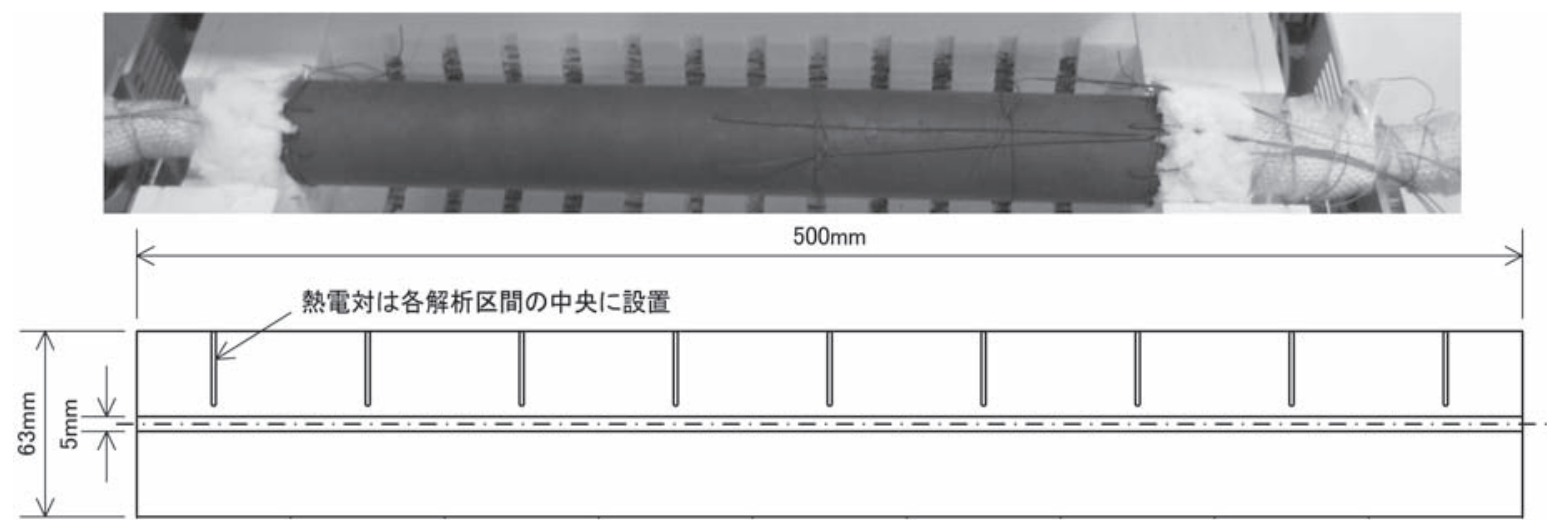

第 2 図 加熱管

度差から以下の式 (1) で与えられる。

$$
q=\frac{2 \pi \lambda\left(T_{\mathrm{ow}}-T_{\mathrm{iw}}\right)}{\ln \left(r_{\mathrm{ow}} / r_{\mathrm{iw}}\right)}
$$

ただし， $\lambda$ は加熱管の熱伝導率 $[\mathrm{W} / \mathrm{m} / \mathrm{K}], T_{\mathrm{ow}}$ と $T_{\mathrm{iw}}$ は それぞれ温度計測位置における加熱管の外側と内側の温度 を示している。 また $r_{\mathrm{ow}}$ と $r_{\mathrm{iw}}$ は温度測定位置の外側と 内側の半径である。本研究では, 第 2 図に示すように 9 つ の断面位置に，管の外側と内側に熱電対を設置して温度を 計測した。温度測定断面は $57.5 \mathrm{~mm}$ ごとに等間隔で 9 断 面設けられており，両端の温度測定位置は，加熱管端より $20 \mathrm{~mm}$ の位置にある。各断面における熱電対による温度測 定位置の半径はそれぞれ $r_{\mathrm{in}}=4.5 \mathrm{~mm}$ と $r_{\mathrm{out}}=28.5 \mathrm{~mm}$ である. 式 (1) で与えられた伝熱量を, 第 2 図に示す解析 区間の伝熱量と仮定し，9 区間ごとに伝熱量を求めて，それ ら和を $\mathrm{MCH} へ$ の伝熱量として評価した. $\mathrm{MCH}$ の流量は, レギュレータでコントロールし，その流量は加熱管とマイ クロケーブルエアーヒーターの間に設置されたオリフィス で流れをチョークさせて流量を計測する。各試験において, 流量, 圧力は約 $1.1 \sim 1.7 \mathrm{~g} / \mathrm{s}$, 約 $1.6 \sim 2.3 \mathrm{MPaA}$ の範囲で ある。

\section{4. 吸熱量 評価}

4.1 窒素ガスによる加熱装置の精度検証 本研究では, $\mathrm{MCH}$ 熱分解加熱試験を行う前に, 実験装置の妥当性を評 価するため, $\mathrm{N}_{2}$ ガスを加熱試験ガスに用いた場合の加熱 試験を行い, 同装置の特性把握と計測精度の確認を行った. 加熱管での単位ガス流量当たりの受熱量 $\Delta q_{\text {input }}$ がすべ て試験ガスのエンタルピー上昇に費やされた場合, $\Delta q_{\text {input }}$ と加熱管の入口及び出口の温度 $T_{\mathrm{in}}, T_{\mathrm{out}}$ の関係は次の式 (2) で表される.

$$
\Delta q_{\text {input }}=h\left(T_{\text {out }}\right)-h\left(T_{\text {in }}\right)
$$

ただし， h は試験ガスの比エンタルピーである. 試験ガスを 比熱一定の完全気体と見なした場合, 式 (2) は式 (3)のよう に加熱管の入口と出口における温度変化 $\Delta T=T_{\mathrm{out}}-T_{\mathrm{in}}$ と $\Delta q_{\text {input }}$ は比例関係で示される.

$$
\Delta T=\frac{\Delta q_{\text {input }}}{C_{P}}
$$

ここでは加熱管壁の温度差を計測することで, $\Delta q_{\text {input }}$ を式 (1) で求め, 更に加熱管の入口と出口の温度を測定し, $\Delta T$ と比エンタルピーの上昇を求めた。比エンタルピーの 評価には文献 5) または6) を引用した。 加熱量 $\Delta q_{\text {input }}$ と 比エンタルピー増分及び温度増分の関係を，それぞれ第 3 図 (a), (b) に示した。図中各点の温度の值は加熱管出口 の温度を示している。また加熱管入口における $\mathrm{N}_{2}$ ガスの 温度は最大で $658.5 \mathrm{~K}$, 最小で $557.9 \mathrm{~K}$ であり, 平均では $621.7 \mathrm{~K}$ であった。また加熱管外壁の最大温度と最小温度 はそれぞれ $1249 \mathrm{~K}$ と $771 \mathrm{~K}$ であった。第 3 図 (a), (b)に はそれぞれ式 (2), (3) で示される理論線も示した。 たたし 式 (3) における定圧比熱 $C_{P}$ は各試験条件における平均入 口温度の值で評価した，これら 2 つの図から, 実験で求め た加熱量は理論線とほぼ一致していることが分かる。これ より，本実験装置を用いることによって，加熱管における 流体への加熱量を適切に評価できることが示された．

$4.2 \mathrm{MCH}$ を用いた試験 前節で本装置の妥当性が示 されたことから, 試験ガスに $\mathrm{MCH}$ を用いて加熱試験を行 い, 加熱量とエンタルピー増加及び温度上昇の相関を計測し た. 第 4 図 (a) と (b)にそれぞれ加熱量 $\Delta q_{\text {input }}$ と $\mathrm{MCH}$ のエンタルピー増加分, 及び温度増加分の関係を示した。 $\mathrm{MCH}$ の比エンタルピーのデータベース ${ }^{6)}$ より, これらの 図にも $\mathrm{MCH}$ の理論エンタルピー曲線と加熱量一温度上昇 線をそれぞれ示した。 $\mathrm{N}_{2}$ ガスの場合とは異なり, 出口ガ ス温度が $900 \mathrm{~K}$ 以上になってくると, 加熱量を増やしても 温度上昇が鈍くなってきていることが分かる。この温度以 上になると $\mathrm{MCH}$ が熱分解し始めて, 加熱量が熱分解に伴 う吸熱量に費やされているためと考えられる。第 4 図 (a) より理論上の温度上昇と実際の温度上昇では，最大 $150 \mathrm{~K}$ の差が生じていることが分かる。第 4 図 (b) には, 加熱量 に対する $\mathrm{MCH}$ エンタルピーの理論増加分の関係を示した. 加熱量がある一定以上になると, 理論的なエンタルピー上 昇が抑制されることが分かり，両者の差は最大で 1.4 倍ま で拡大している。この差は $\mathrm{MCH}$ の熱分解によって, 吸収 された吸熱量であると考えられる. 


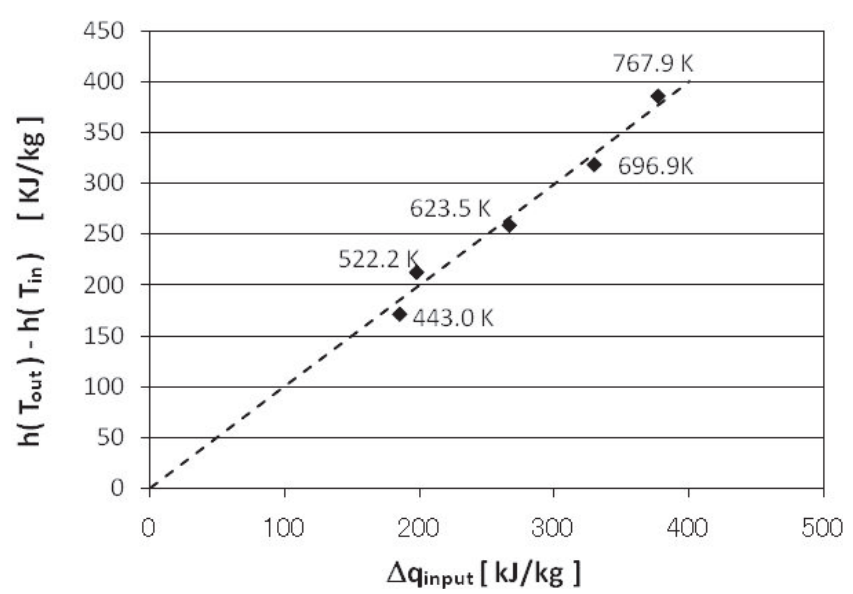

(a) 単位質量当たりの加熱量と比エンタルピー上昇の関係（図中の 温度は加熱管外壁温度)

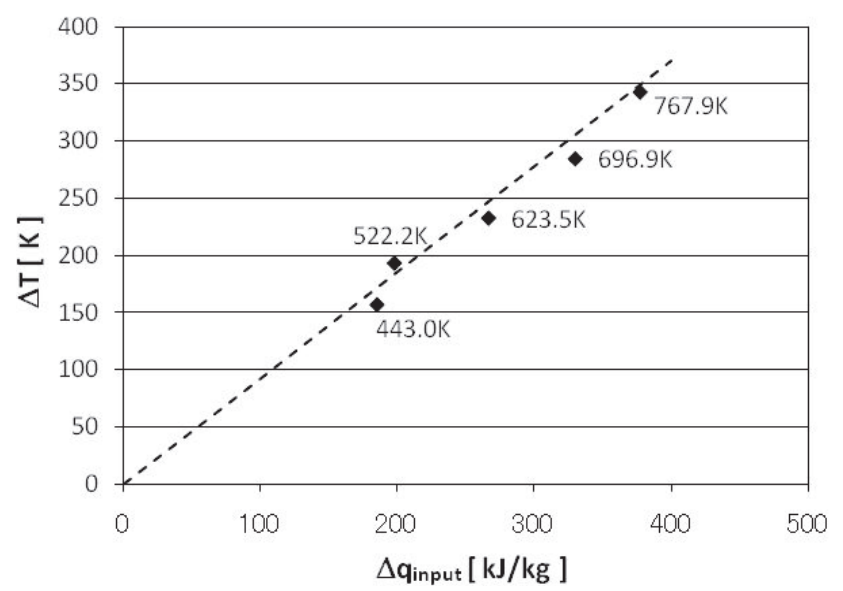

(b) 単位質量当たりの加熱量と温度上昇の関係（図中の温度は加熱 管外壁温度)

第 3 図窒素ガスを用いた加熱試験結果

次に最大加熱時（電気炉設定値 $1273 \mathrm{~K}$ ）における $\mathrm{MCH}$ ガスのガスサンプリングを示す，できるだけ多くの化学種の 存在を捉えるため, ガス成分分析にはカラムの異なる FID ガ スクロマトグラフィー 2 台と TCD ガスクロマトグラフィー 1 台を用いて分析を行った。第 2 表はその時の主な分解ガ スの化学種成分の一覧である。この表より，84\%の $\mathrm{MCH}$ が熱分解していることが判明した，また水素の存在も確認 できることから，メチルシクロヘキサンは脱水素反応が起 こっていることが分かるが, 熱分解ガスにはメタンやエチ レンなどの低分子量の炭化水素が多く含まれていることか ら, $\mathrm{MCH}$ の熱分解は, トルエンと水素を発生する脱水素 反応というょり，炭素結合が切れた Thermal Cracking が 主であったことが分かる. トルエンと水素を生成する脱水 素反応は白金等の触媒が必要であると考えられる。

本節の結果からも， $\mathrm{MCH}$ の投入熱量に対して温度が上 がらなくなる現象は脱水素反応や熱分解反応による吸熱反 応により吸熱されたためと考えられる。

電気炉から $\mathrm{MCH}$ に与える熱流束を，加熱管の温度差か ら計測した，第 5 図は縦軸に単位質量流量当たりの熱流束, 横軸に加熱管軸方向における熱流束測定区間をとったグラ

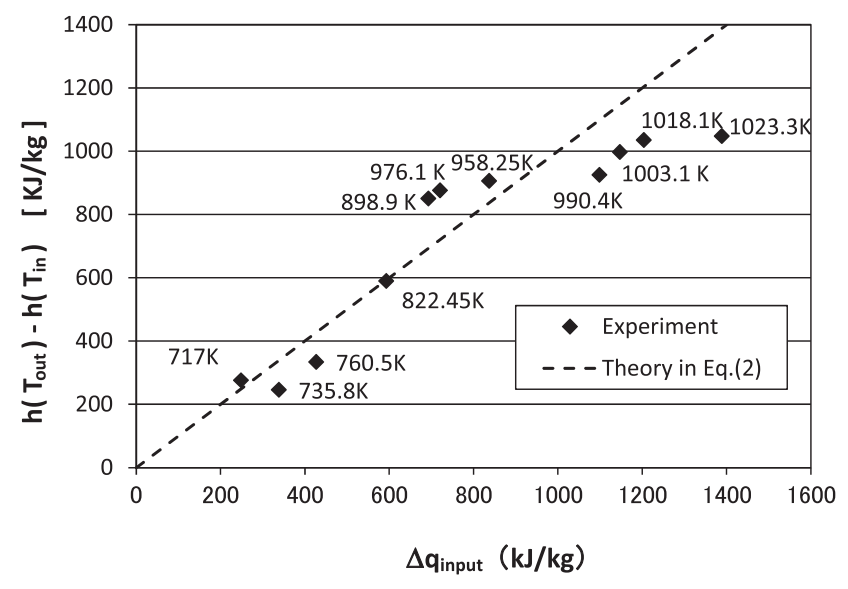

(a) 単位質量当たりの加熱量と比エンタルピー上昇の関係（図中の 温度は加熱管出口温度)

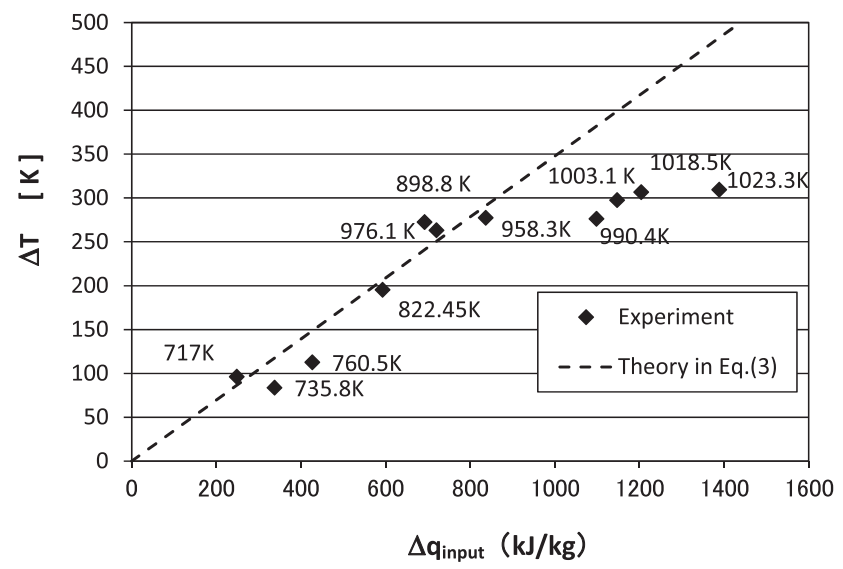

(b) 単位質量当たりの加熱量と温度上昇の関係（図中の温度は加熱 管出口温度)

第 4 図 $\mathrm{MCH}$ を用いた加熱試験結果

\begin{tabular}{lr}
\multicolumn{2}{l}{ 第2 表 } \\
\hline MCH & $16 \%$ \\
\hline Methane & $36 \%$ \\
\hline Hydrogen & $2 \%$ \\
\hline Ethane & \\
Ethylene & \\
Benzene & \\
Other hydrocarbon & \\
\hline
\end{tabular}

フである，グラフの左側が上流側（管入口）で右側が下流 側（管出口）に相当する.

第 5 図 (a) の $\mathrm{N}_{2}$ のグラフを見ると, 電気炉の設定温度を $873 \mathrm{~K}$ から $1273 \mathrm{~K}$ まで $100 \mathrm{~K}$ ずつ昇温させると, 熱流束 はほぼ一定に上昇していることが確認できる，加熱区間ご との加熱量を積分すると, 大体電気炉の設定温度を $100 \mathrm{~K}$ 上昇させると, 加熱管全体で約 1.1 1.3 倍の熱流束の増加 となっていた，その一方で $\mathrm{MCH}$ の加熱試験に扔ける熱流 束は, 電気炉の設定温度を $1073 \mathrm{~K}$ から $1173 \mathrm{~K}$ に上昇さ せた時で，熱流束が大幅に増加していることが分かる。 ま た上記電気炉設定温度では加熱管出口の $\mathrm{MCH}$ 温度がそれ ぞれ $898 \mathrm{~K}$ と $990 \mathrm{~K}$ であったことから， MCH を $900 \mathrm{~K}$ 以 
第 3 表 $\mathrm{MCH}$ の熱分解反応モデル8) (単位 $: \mathrm{kmol}, \mathrm{m}, \mathrm{K}, \mathrm{sec}$ )

\begin{tabular}{|c|c|c|c|}
\hline & 反応式 & $A$ & $E / R$ \\
\hline 1 & $\begin{aligned} & \mathrm{MCH} \rightarrow 0.05 \mathrm{H}+0.35 \mathrm{CH}_{3}+0.3 \mathrm{C}_{2} \mathrm{H}_{5}+0.05 c y-\mathrm{C}_{6} \mathrm{H}_{10}+0.3 \mathrm{C}_{4} \mathrm{H}_{6} \\
&+0.3 \mathrm{C}_{2} \mathrm{H}_{4}+0.35 \mathrm{C}_{3} \mathrm{H}_{6}+0.2 \mathrm{C}_{4} \mathrm{H}_{8}+0.15 \mathrm{i}-\mathrm{C}_{4} \mathrm{H}_{8}+0.2 \mathrm{C}_{5} \mathrm{H}_{10} \\
&\end{aligned}$ & $5.00 \mathrm{E}+17$ & 41300 \\
\hline 2 & $\begin{aligned} \mathrm{R}+\mathrm{MCH} \rightarrow & \mathrm{RH}+\mathrm{R}-\mathrm{C}_{7} \mathrm{H}_{13} \\
\mathrm{R}-\mathrm{C}_{7} \mathrm{H}_{13} \rightarrow & 0.05 \mathrm{H}+0.28 \mathrm{CH}_{3}+0.35 \mathrm{C}_{2} \mathrm{H}_{5}+0.15 \mathrm{n}-\mathrm{C}_{3} \mathrm{H}_{7}+0.10 \mathrm{i}-\mathrm{C}_{3} \mathrm{H}_{7} \\
& +0.12 \mathrm{p}-\mathrm{C}_{4} \mathrm{H}_{7}+0.20 \mathrm{C}_{2} \mathrm{H}_{4}+0.12 \mathrm{C}_{3} \mathrm{H}_{6}+0.39 \mathrm{C}_{4} \mathrm{H}_{6} \\
& +0.05 \mathrm{cy}-\mathrm{C}_{5} \mathrm{H}_{8}+0.05 \mathrm{cy}-\mathrm{C}_{5} \mathrm{H}_{6}+0.29 \mathrm{C}_{5} \mathrm{H}_{8}+0.10 c y-\mathrm{C}_{6} \mathrm{H}_{10}\end{aligned}$ & $5.00 \mathrm{E}+13$ & 15100 \\
\hline
\end{tabular}

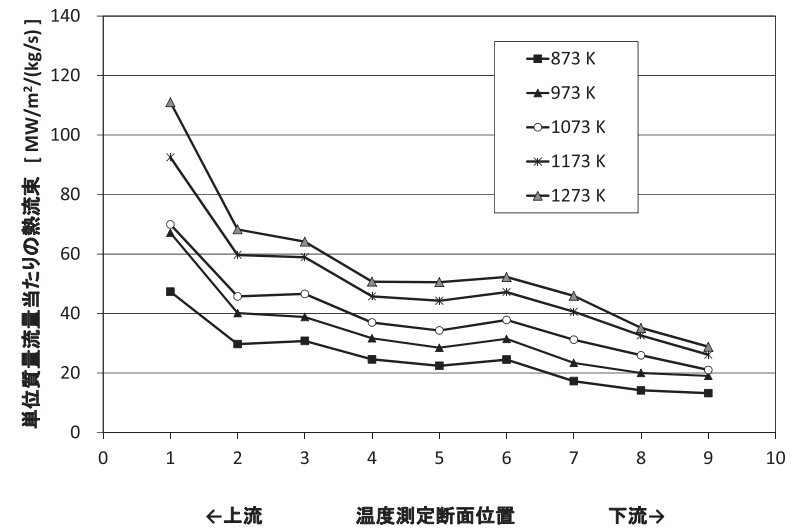

(a) $\mathrm{N}_{2}$

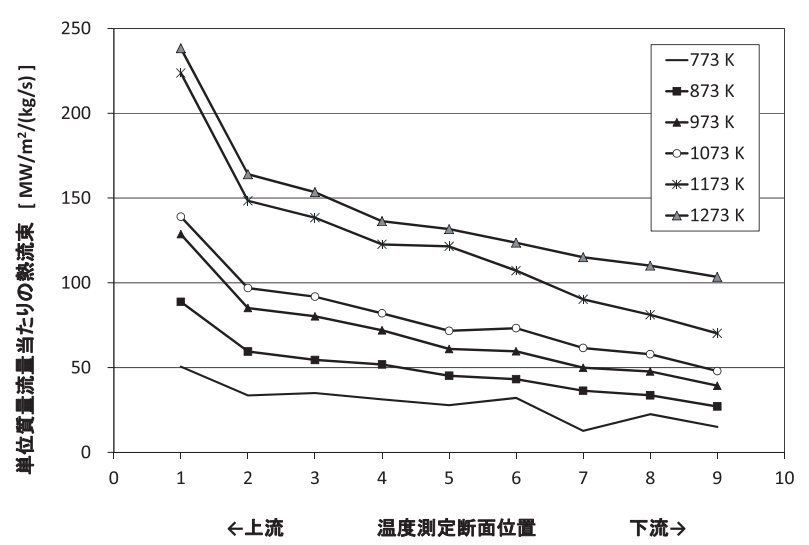

(b) $\mathrm{MCH}$

第 5 図 加熱管の各断面における熱流束の軸方向変化

上に加熱すると熱分解反応が起きて, 吸熱反応による熱流 束の増加が起こるものと考えられる。なお，加熱管入口で の $\mathrm{N}_{2}$ と $\mathrm{MCH}$ の熱流束の違いは加熱管入口温度を 600〜 $700 \mathrm{~K}$ の範囲に調整しているため, 各ガスの物性の違いに よるものと考えられる.

\section{5. $\mathrm{MCH}$ 熱分解に関する解析}

前節で述べた実験結果から， $\mathrm{MCH}$ は $900 \mathrm{~K}$ 以上に加熱 すると熱分解反応が起こることが実験的に確認された。本 研究では, $\mathrm{MCH}$ の熱分解反応を数值シミュレーションに よって再現することを試みた。

$\mathrm{MCH}$ の熱分解反応に関する詳細素反応モデルには, 主 なものだけでも 300 近くの素反応を考慮する必要があり7), 数值解析でそれらをすべて扱うのは容易なことではない. 一方で Granata らは第 3 表に示すような 2 段階の反応式

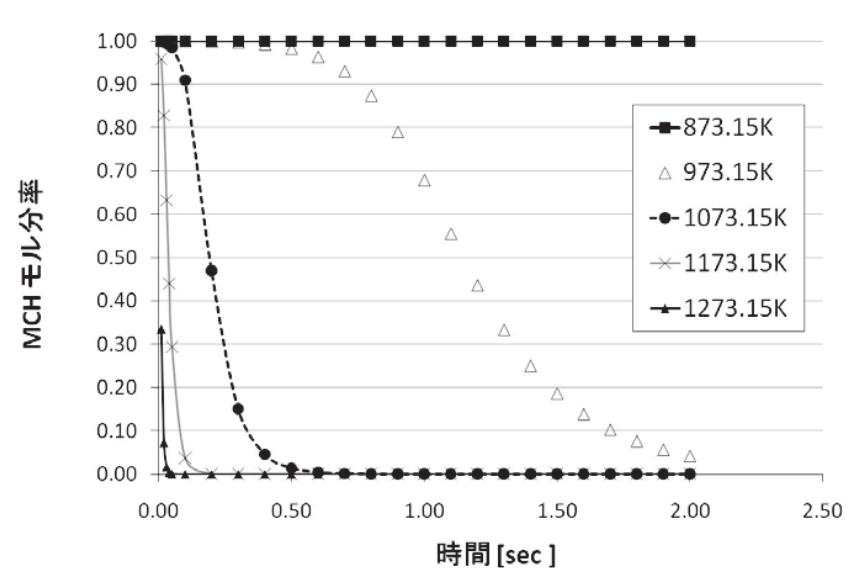

第 6 図 $\mathrm{MCH}$ の熱分解反応数值解析結果

で成り立つ反応モデルを提唱している8)。この反応モデル における，アレニウス型反応速度定数 $k$ に関する速度定数 を第 3 表に示した.

$$
k=A \exp \left(-\frac{E}{R T}\right)
$$

本研究では解析の容易さの面から, この反応モデルを使っ て $\mathrm{MCH}$ の熱分解反応をシミュレーションしてみることに した，第 6 図は，MCH 100\%のガスを大気圧下で，加熱温 度を一定に保持した場合の， $\mathrm{MCH}$ モル分率の時間履歴を 示したものである。この解析結果も $\mathrm{MCH}$ は $873 \sim 973 \mathrm{~K}$ を境に熱分解反応が開始することを示している．これらの 解析結果は本研究の実験結果の傾向と一致している. $\mathrm{MCH}$ の熱分解開始温度が，実験的にも解析的にも 873 973 K から開始していることが分かる。

\section{6. 結言}

本研究では, 次世代極超音速機等の再生冷却システムへ の応用を目的に, メチルシクロヘキサン $(\mathrm{MCH})$ の熱分解 吸熱反応と吸熱量を評価した。 $\mathrm{MCH}$ の熱分解開始温度を 実験的・解析的に同定した。これらの結果は以下の通りと なる。

(1) 分解吸熱作用により温度上昇が理論值と比較して最大 で $150 \mathrm{~K}$ 近く降下することが確認された。

(2) その際, 熱分解を伴った $\mathrm{MCH}$ の等価的熱容量は最大 で約 1.4 倍増加していた.

(3) Granata らによる, MCHの 2 段階熱分解反応モデル を用いて，数值シミュレーションを行った結果， MCH は $873 \mathrm{~K}$ から $973 \mathrm{~K}$ にて熱分解反応が起こる。これは実験結 
果の傾向と一致している.

以上から，熱分解吸熱反応による吸熱量を定量的に評価 することができ，再生冷却システムに利用する燃料として 熱分解吸熱反応燃料を利用することの有用性を示すことが できた，今後は白金等の触媒を用いることによって，再生 冷却システムにより適用できるように $\mathrm{MCH}$ の熱分解反応 をコントロールしていくことが課題である.

\section{参 考 文 献}

1) Edwards, T.: Liquid Fuels and Propellants for Aerospace Propulsion: 1903-2003, J. Propul. Power, 19 (2003), pp. 1089-1107.

2) Landar, H. and Nixon, A. C.: Endothermic Fuels for Hypersonic Vehicles, J. Aircraft, 8 (1971), pp. 200-207.

3) Powell, O. A., Edwards, T., Norris, R. B., Numbers, K.
E. and Pearce, J. A.: Development of Hydrocarbon-Fueled Scramjet Engine: The Hypersonic Technology (HyTech) Program, J. Propul. Power, 17 (2001), pp. 1170-1176.

4) 関東化学株式会社：メチルシクロヘキサン製品安全データシート, 2010.

5) Chase, M. W.: NIST-JANAF Thermochemical Tables, 4th ed., the American Chemical Society and the American Institute of Physics for the National Institute of Standard and Technology, Gaithersburg, Maryland, 1998.

6) National Institute of Standard and Technology (NIST) Chemistry WebBook, http://webbook.nist.gov/chemistry/

7) Orme, J. P., Curran, H. J. and Simmie, J. M.: Experimental and Modeling Study of Methylcyclohexane Pyrolysis and Oxidation, J. Phys. Chem. A, 110 (2006), pp. 114-131.

8) Granata, S., Faravelli, T. and Ranzi, E.: A Wide Range Kinetic Modeling Study of the Pyrolysis and Combustion of Naphthenes, Combust. Flame, 132 (2003), pp. 533-544. 